\title{
RETHINKING A SUSTAINABLE TRUFFLE SECTOR UNDER GLOBAL CRISES
}

\author{
Ulf Büntgen, Tomáš Čejka, Mirek Trnka and Paul W. Thomas
}

With 1 figure

\begin{abstract}
Summary: Global climate change is the main threat for the emerging truffle sector, which already extends across seven key regions in the Americas, Europe, South Africa and Australasia. At the same time, the potential effects of financial crises and global pandemics have not yet been considered in most risk assessments. Here we describe the direct and indirect impacts of the actual coronavirus pandemic on the rising truffle sector. We discuss how COVID-19 affects small family businesses and international enterprises, and if the current harvest decline will have ecological long-term benefits. Furthermore, we question extant cultivation practices, irrigation techniques and trade systems to prepare for a more equitable and sustainable future of the global truffle industry. Despite various foci on one of the most expensive gourmet foods and its associated agroforestry, we expect our reflections to be valuable for many other high-value crops, and a green agriculture in general.
\end{abstract}

Zusammenfassung: Der globale Klimawandel stellt die größte Herausforderung für den wachsenden Trüffelsektor dar, welcher sich innerhalb der letzten Jahre in sieben Regionen in Nord- und Süd Amerika, Europa, Süd Afrika, Australien und Neuseeland ausgebreitet und etabliert hat. Während negative Effekte von Hitzewellen und Dürreperioden für die Trüffelproduktion bekannt sind, wurden mögliche Folgen globaler Finanzkrisen und Pandemien bisher kaum bis gar nicht in bestehenden Risikoeinschätzungen berücksichtigt. In der vorliegenden Studie beschreiben wir die direkten und indirekten Konsequenzen der aktuellen Corona Pandemie auf den noch jungen Trüffelsektor. Wir diskutieren wie sich COVID-19 auf kleine Familienbetriebe und internationale Unternehmen auswirkt und ob reduzierte Trüffelernten einen ökologischen Langzeitnutzen haben. Außerdem hinterfragen wir bestehende Anbaumethoden, Bewässerungstechniken und Handelsbeziehungen im Hinblick auf eine gerechtere und nachhaltigere Trüffelindustrie. Wir hoffen das unsere kritische Auseinandersetzung mit der teuersten Delikatesse und deren Waldfeldbau nicht nur für andere Agrarprodukte, sondern ganz allgemein auch für eine Grüne Landwirtschaft hilfreich ist.

Keywords: biodiversity, COVID-19, economic crises, global pandemic, gourmet food, green-agriculture, irrigation systems, reforestation, rural economies

Farming of the Périgord black truffle (Tuber melanosporum Vitt.) has expanded rapidly during the past decades. With $\sim 2.3$ million $\mathrm{km}^{2}$ of suitable truffle terrain across seven key regions in the Americas (Chile, California and Oregon), southern Europe (Spain, France and Italy), South Africa (the KwaZulu-Natal and Western Cape regions) and Australasia (southwest and eastern Australia and most of New Zealand), the emerging truffle sector - an important agroforestry practice - generates hundreds of millions of Euros annually (FISCHER et al. 2017; OliaCH et al. 2020). Enhanced cultivation techniques and an ever-growing number of plantations since the mid 2000s not only trigger economic benefits for rural areas (Hall et al. 2003; DonNini et al. 2013; BÜNTGEN et al. 2017), but also increase landscape diversity and water-holding capacity (Reyna and Garcia-Barreda 2014). Comparable to mycotourism (BüNTGEN et al. 2017), a thriving truffle sector can also support local and regional infrastructure, biodiversity and environmental awareness.

(c) (1) https://doi.org/10.3112/erdkunde.2021.04.06
Similar to ecological and agricultural systems that are particularly prone to drought extremes and heat waves (TRNKA et al. 2020; BÜNTGEN et al. 2021b; OLESEN et al. 2021), anthropogenic climate change has been described as the main threat for the quality and quantity of truffle harvests (BÜNTGEN et al. 2012, 2019; THOMAS and Büntgen 2019; Garcia-Barreda et al. 2020), which can exhibit an essential non-wood forest product for sustainable silviculture (DonNINI et al. 2013). However, risk assessments of the truffle sector do not consider the cascading effects of financial or other global crises. Reportedly, the current coronavirus pandemic (COVID-19) hits the sector at an unprecedented scale (https://www.reuters.com/article/croatia-truffles-idINL8N2IC3D9). While the direct and indirect impacts of the unfolding pandemic on agricultural production and trade have not yet been quantified (BECKMAN and Countryman 2021), we argue that the devastating consequences for the truffle sector will affect small family businesses as well as global enterprises, with implications for the wider food industry (RIDLEY and Devadoss 2020; Chenarides et al. 2021).

ISSN 0014-0015 (Print) · ISSN 2702-5985 (Online) 
Like academia (BüntGen et al. 2021a) and the wider mushroom agroindustry (HARVATI 2021), including mycotourism (BüNTGEN et al. 2017), the influence of COVID-19 restrictions on truffle hunters, farmers, harvesters, sellers, and consumers has been inescapable (Fig. 1A). With pandemic-related enforced closures, demand from the most important market for truffles, the high-end restaurant sector, has suddenly declined. First grade fruitbodies of the Périgord black truffle are currently offered in the US for \$320USD/ lb (January 2021), which is less than half of the regular in-season value. Moreover, truffle festivals, such as the annual Napa Truffle Festival in California (USA) or the Trufforum in Catalonia (Spain) have been cancelled for the 2020/2021/2022 harvest season, and many traditional markets and socio-cultural events are forced to close (Fig. 1B). Associated declines in employment levels may have a direct impact on household income, creating financial frictions and liquidity constraints. These impact property and housing markets directly and can lead to further declines in local employment levels (BRANCH et al. 2016). Therefore, the socio-economic consequences of declining truffle harvests can be complex and may exist at national and international scales (Fig. 1B).

Low truffle prices, combined with pandemic-related travel and trade disruptions have led some orchards to abandon harvesting for at least the 2020/21 season. Imposed movement restrictions in response to infection levels further impact large numbers of farm la- bourers, and in Italy alone, this may affect over 100,000 seasonal workers and their truffle-search dogs. Indeed, the reduction in truffle prices and loss of peripheral truffle-related industries is particularly harmful for rural populations where such activities are centred (BüNTGEN et al. 2017), and the direct loss of cultivators' income is not the only issue. In California (the largest truffle cultivation region in the Americas), for example, COVID-19 is likely to impact lower-wage agricultural workers disproportionally, and so staff shortages have been reported as being directly related to high rates of infections. Despite reduced labour availability, the maintenance of plantations has been largely continued under reduced capacity, although in the future the overall damage will likely depend on de-synchronisation of virus outbreaks and harvesting activities.

In contrast to the immediate economic constraints, there are potentially two long-term advantages of the current harvest decline (Fig. 1C). Firstly, the hypogeous nature of truffles leads to a dependence on mycophagy for spore dispersal. Consequently, there are many vertebrate and invertebrate species that predate them and in doing so, truffles may form an important component of animal food webs (Trappe, 2009). Although ecological networks are complex and multifactorial, the increase in unharvested fruiting bodies, especially in natural habitats, is likely to benefit populations of truffle specialists such as some flies of the genus Suillia (e.g., S. tuberiperda) and associated food chains (Rosa-Gruszecka et al. 2017). Secondly,
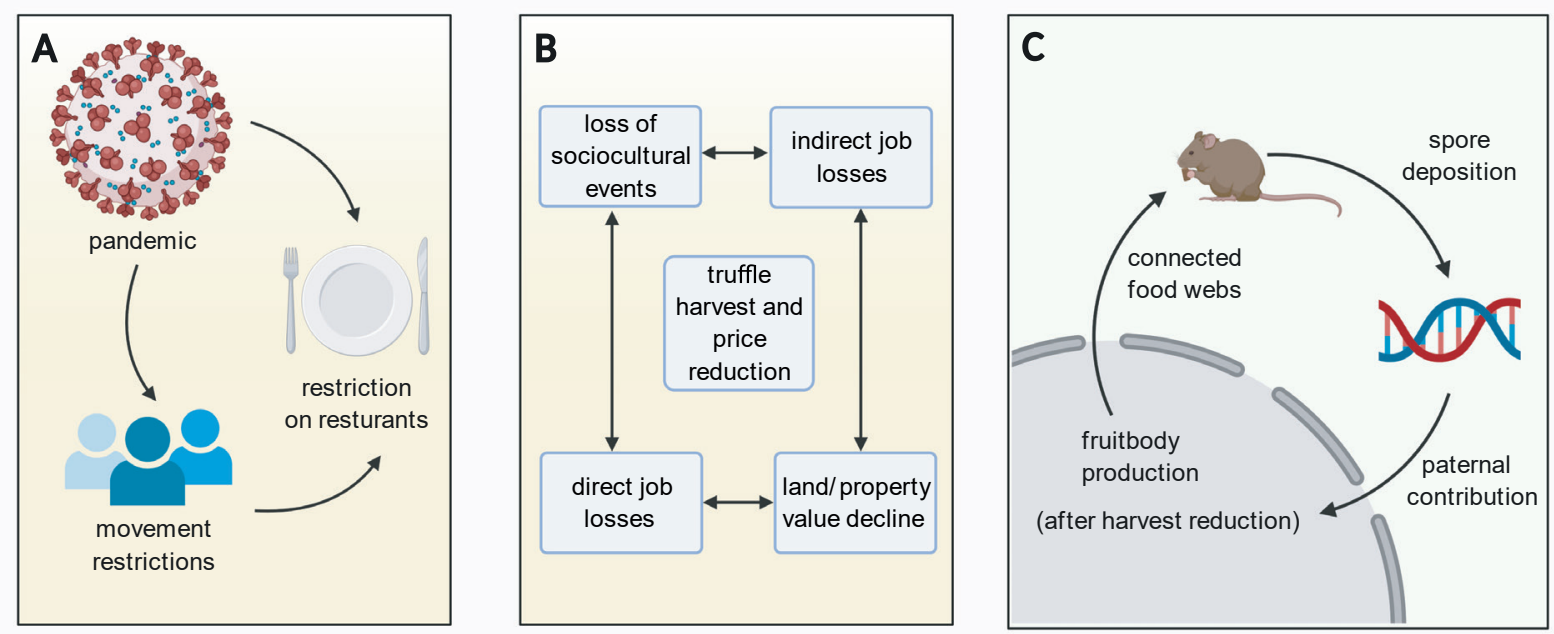

Fig. 1: Effects of the global coronavirus pandemic (COVID-19) on the emerging truffle sector. (A) Direct COVID-19 impacts on social movement patterns and the enforced closure of truffle markets and restaurants. (B) Socio-economic consequences of current COVID-19 restrictions on personal and monetary goods associated with declining truffle harvests and price reductions at local/national and global/international scales. (C) Long-term benefits of dampened truffle harvesting practices due to COVID-19 restrictions on natural and agricultural food webs and enhanced truffle fruitbody production. Reduced truffle harvests will likely result in greater spore availability, thus aiding to sexual reproduction and leading to greater fruitbody production. 
a reduction in truffle harvesting may enhance future fruitbody production, because an increase in the truffle spore-bank of the soil from decomposing fruitbodies or faecal matter arising from truffle predation is beneficial to mycelial development (SCHNEIDERMaunoury et al. 2019). Further, the most widely harvested Périgord black truffle is dependent on sexual reproduction for fruitbody formation, and it has been suggested that paternal contributions arise from the soil spore bank (TASCHEN et al. 2016; FISCHER et al. 2017). Thus, reduced harvesting pressure may in turn pay dividends by contributing to enhanced truffle yields in the future.

A purely market-oriented truffle industry, considered among many to be luxurious but dispensable, will always remain vulnerable to market changes and financial crises. The high-value nature of truffle production, combined with significant inter-orchard variation, has created a climate of envy and frustration among farmers and investors that threatens the ethical and professional standards of both green-agriculture and eco-tourism. If the marketing and promotion of truffles and their secondary products absorbs more time and receives more rewards than the effort to engage in sustainable hunting and farming, there will be little incentive to explore new pathways of ecological farming and fair trading. COVID-19 forces the vibrant sector to reflect on its goals and the ways to achieve them. The current restrictions present fresh opportunities to question extant cultivation practices, irrigation techniques and trade systems, and to prepare for a more equitable and sustainable future.

\section{Funding}

This research was funded by the Ministry of Education, Youth and Sports, grant number CZ.02 .1.01/0.0/0.0/16_019/0000797 (SustES - Adaptation strategies for sustainable ecosystem services and food security under adverse environmental conditions), and Masarykova univerzita, grant number MUNI/A/1570/2020 (Geografický výzkum dynamiky přírodních a společenských prostorových procesů GEODYN).

\section{References}

Beckman, J. and Countryman, A. (2021): The importance of agriculture in the economy: Impacts from COVID-19. In: American Journal of Agricultural Economics 103, 1595-1611. https://doi.org/10.1111/ajae.12212
Branch, W. A.; Petrosky-Nadeau, N. and Rocheteau, G. (2016): Financial frictions, the housing market, and unemployment. In: Journal of Economic Theory 164, 101-135. https://doi.org/10.1016/j.jet.2015.07.008

Büntgen, U.; Egli, S.; Camarero, J. J.; Fischer, E. M.; StobBe, U.; Kauserud, H.; Tegel, W.; Sproll, L. and StenSETH, N. C. (2012): Drought-induced decline in Mediterranean truffle harvest. In: Nature Climate Change 2, 827-829. https://doi.org/10.1038/nclimate1733

Büntgen, U.; Latorre, J.; Egli, S. and Martínez-Peña, F. (2017): Socio-economic, scientific, and political benefits of mycotourism. In: Ecosphere 8, e01870. https://doi. org/10.1002/ecs 2.1870

Büntgen, U.; Oliach, D.; Martínez-Peña, F.; Latorre, J.; EgLI, S. and Krusic, P. J. (2019): Black truffle winter production depends on Mediterranean summer precipitation. In: Environmental Research Letters 14, 074004. https://doi.org/10.1088/1748-9326/ab1880

Büntgen, U.; Krusic, P. J. and Di Cosmo, N. (2021a): Science in silence. In: Erdkunde 75 (1), 61-63. https:/ / doi. org/10.1088/1748-9326/ab1880

Büntgen, U.; Urban, O.; Krusic, P. J.; Rybníček, M.; Kolár̆, T.; Kyncl, T.; AČ, A.; Koñasová, E.; Čáslavsky, J.; EsPer, J.; Wagner, S.; Saurer, M.; Tegel, W.; Dobrovonly, P.; Cherubini, P.; Reinig, F. and Trnka, M. (2021b): Recent European drought extremes beyond Common Era background variability. In: Nature Geoscience 14, 190-196. https://doi.org/10.1038/s41561-021-00698-0

Chenarides, L.; Manfredo, M. and Richards, T. J. (2021): COVID-19 and food supply chains. In: Applied Economic Perspectives and Policy 43, 270-279. https:/ /doi. org/10.1002/aepp.13085

Donnini, D.; Gargano, M.L.; Perini, C.; Savino, E.; Murat, C.; Di Piazza, S.; Altobelli, E.; Salerni, E.; Rubini, A.; Rana, G. L.; Bencivenga, M.; Venanzoni, R. and ZamBONELLI, A. (2013): Wild and cultivated mushrooms as a model of sustainable development. In: Plant Biosystems 147, 226-236. https://doi.org/10.1080/11263504.2012 .754386

Fischer, C. R.; Oliach, D.; Bonet, J. A. and Colinas, C. (2017): Best practices for cultivation of truffles. Forest sciences centre of Catalonia and Yaşama Dair Vakıf. http://hdl.handle.net/10459.1/62828

Garcia-Barreda, S.; Camarero, J. J.; Vicente-Serrano, S. M. and Serrano-Notivoli, R. (2020): Variability and trends of black truffle production in Spain (1970-2017): linkages to climate, host growth, and human factors. In: Agricultural and Forest Meteorology 287, 107951. https://doi.org/10.1016/j.agrformet.2020.107951

Hall, I. R.; Yun, W. and Amicucci, A. (2003): Cultivation of edible ectomycorrhizal mushrooms. In: Trends in Biotechnology 21, 433-438. https://doi.org/10.1016/ S0167-7799(03)00204-X 
Harvati, N. (2021): Business model analysis of mushroom agroindustry and its sustainable development strategy in Covid-19 pandemic. In: IOP Conference Series: Earth and Environmental Science 733, 012125. https://doi. org/10.1088/1755-1315/733/1/012125

Olesen, J.; Trnka, M.; Kersebaum, K. C.; Skjelvåg, A. O.; Seguin, B.; Peltonen-Sainio, P.; Rossi, F.; Kozyra, J. and Micale, F. (2011): Impacts and adaptation of European crop production systems to climate change. In: European Journal of Agronomy 34, 96-112. https:// doi.org/10.1016/j.eja.2010.11.003

Oliach, D.; Colinas, C.; Castaño, C.; Fischer, C. R.; BolaÑo, F.; Bonet, J. A. and Oliva, J. (2020): The influence of forest surroundings on the soil fungal community of black truffle (Tuber melanosporum) plantations. In: Forest Ecology and Management. 469, 188199. https://doi. org/10.1016/j.foreco.2020.118199

Reyna, S. and Garcia-Barreda, S. (2014): Black truffle cultivation: a global reality. In: Forest Systems 23, 317-328. https://doi.org/10.5424/fs/2014232-04771

Ridley, W. and Devadoss, S. (2020): The effects of COVID-19 on fruit and vegetable production. In: Applied Economic Perspecives and Policy 43, 329-40. https:// doi.org/10.1002/aepp.13107

Rosa-Gruszecka, A.; Gange, A. C.; Harvey, D. J.; Jaworski, T.; Hilszczański, J.; Plewa, R.; Konwerski, S. and HilszczańsKA， D. (2017): Insect-truffle interactionspotential threats to emerging industries. In: Fungal Ecology 25, 59-63. https://doi.org/10.1016/j.funeco.2016.10.004

Schneider-Maunoury, L.; Taschen, E.; Richard, F. and SElosse, M. A. (2019): Soil spore bank in Tuber melanosporum: up to $42 \%$ of fruitbodies remain unremoved in managed truffle grounds. In: Mycorrhiza 29, 663-668. https://doi.org/10.1007/s00572-019-00912-3

Taschen, E.; Rousset, F.; Sauve, M.; Benoit, L.; Dubois, M. P.; Richard, F. and Selosse, M. A. (2016): How the truffle got its mate: insights from genetic structure in spontaneous and planted Mediterranean populations of $\mathrm{Tu}$ ber melanosporum. In: Molecular Ecology 25, 5611-5627. https://doi.org/10.1111/mec.13864

Thomas, P. and Büntgen, U. (2019): A risk assessment of Europe's black truffle sector under predicted climate change. In: Science of The Total Environment 655, 27-34. https://doi.org/10.1016/j.scitotenv.2018.11.252

Trappe, J. M. (2009): Diversity, ecology, and conservation of truffle fungi in forests of the Pacific Northwest. US Department of Agriculture, Forest Service, Pacific Northwest Research Station. https://doi.org/10.2737/ PNW-GTR-772

Trnka, M.; Balek, J.; Semenov, M. A.; Semeradova, D.; Belinova, M.; Hlavinka, P.; Olesen, J. E.; Eitzinger, J.; Schaumberger, A.; Zahradnicek, P.; Kopecky, D. and Žalud, Z. (2020): Future agroclimatic conditions and implications for European grasslands. In: Biologica Plantarum 64, 865-880. https://doi.org/10.32615/ bp.2021.005

\section{Authors}

Prof. Dr. Ulf Büntgen

Department of Geography University of Cambridge Cambridge CB2 3EN

UK ulf.buentgen@geog.cam.ac.uk

Swiss Federal Research Institute WSL 8903 Birmensdorf Switzerland

Global Change Research Institute of the Czech Academy of Sciences 60300 Brno Czech Republic

Department of Geography Faculty of Science Masaryk University 61300 Brno Czech Republic

Tomáš Čejka Global Change Research Institute of the Czech Academy of Sciences 60300 Brno Czech Republic

Department of Geography Faculty of Science Masaryk University 61300 Brno Czech Republic

Prof. Dr. Mirek Trnka Global Change Research Institute of the Czech Academy of Sciences 60300 Brno Czech Republic

Prof. Dr. Paul W. Thomas Faculty of Natural Sciences University of Stirling FK9 4LA Stirling, UK 